\title{
DEVELOPMENT OF MODEL BLENDED LEARNING IN COOPERATIVE LEARNING FOR TECHNOLOGY AND ENGINEERING SKILLS IN VOCATIONAL EDUCATION
}

\section{Tuti Suartini*}

Departement of Electrical Engineering Education

Universitas Pendidikan Indonesia

Indonesia

tutisuartini@upi.edu

\section{Sisca Elvyanti}

Departement of Electrical Engineering Education

Universitas Pendidikan Indonesia

Indonesia

sisckael@upi.edu

\section{Enjang Akhmad Juanda}

Departement of Electrical Engineering Education

Universitas Pendidikan Indonesia

Indonesia

juanda@upi.edu

\section{Tari Pramanik}

Departement of Electrical Engineering Education

Universitas Pendidikan Indonesia

Indonesia

taripramanik@gmail.com

*Corrosponding author's Email: tutisuartini@upi.edu

Peer-review under responsibility of 5 th $^{d}$ Asia International Conference 2019 Scientific Committee http://connectingasia.org/scientific-committee/

(C) 2019 Published by Readers Insight Publisher, lat 306 Savoy Residencia, Block 3 F11/1,44000 Islamabad. Pakistan,

editor@readersinsight.net

This is an open access article under the CC BY-NC-ND license (http://creativecommons.org/licenses/by-nc-nd/4.0/). 


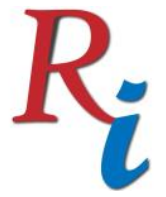

Asia Proceedings of Social Sciences

(APSS)

www.readersinsight.net/APSS

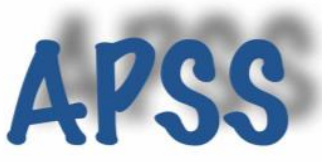

\section{A b s tract}

Increasing the interest and willingness of students to learn a material was determined from the behavior of students in used information communication technology. The learning model developed was a cooperative learning model based on Blended Learnng. Utilization of information technology, by not leaving the pattern of direct guidance from instructors and the used of learning resources to improve literacy mastery of abilities in technology and engineering became important. The Research and Development (R\&D) procedure used Blended learning cooperative learning model design in the form of online and face-to-face learning for ICT literacy subjects and learning media in the experimental and control classes. Blended Learning based cooperative learning models were carried out with scenarios namely offering participation in the experimental class, forming learning groups, and learning activities (lecturers, group tutor teams, students, evaluations). The purpose of this research is to get the quality of learning activities. In stage I, students were offered to take the experimental class and the Control class. The study was conducted by 16 students be taken for experimental classes and 21 be taken for control classes. Based on the results of the study showed that the level of mastery of literacy of ICT and media (n-gain) learning in the experimental class was higher than the control class.

Keywords : Blended Learning, Cooperative Learning, Technology and Engineering

\section{Rese a r ch H igh I ight s}

The research method used to produce certain products, and test the effectiveness of this product. The research carried out is due to the fundamental phenomenon of education for the 4.0 era which requires innovation that is different from the era of traditional education. The position of the teacher as a facilitator in learning activities through a web system that is managed by a tutor. Learning activities begin with all the material files and assignments created by group 1 uploaded by the tutor are placed in a folder which is a task that must be done by another group. Education for computers includes computer literacy and training in software and hardware. The results of the study explain the existence of computers for education, which are controlled through a system of "supervised", "based" and "supported" can be a teaching process in Blended in Cooperative Learning (BCL). In the testing phase of the 


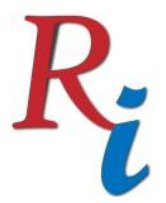

\section{Asia Proceedings of Social Sciences \\ (APSS) \\ www.readersinsight.net/APSS}

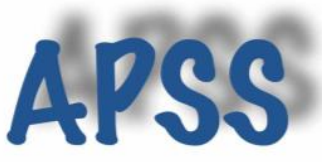

design of online learning models conducted in Computer Literacy Technology and learning media https://medialiterasiict.com have been successful.

\section{Graphical A bstract}

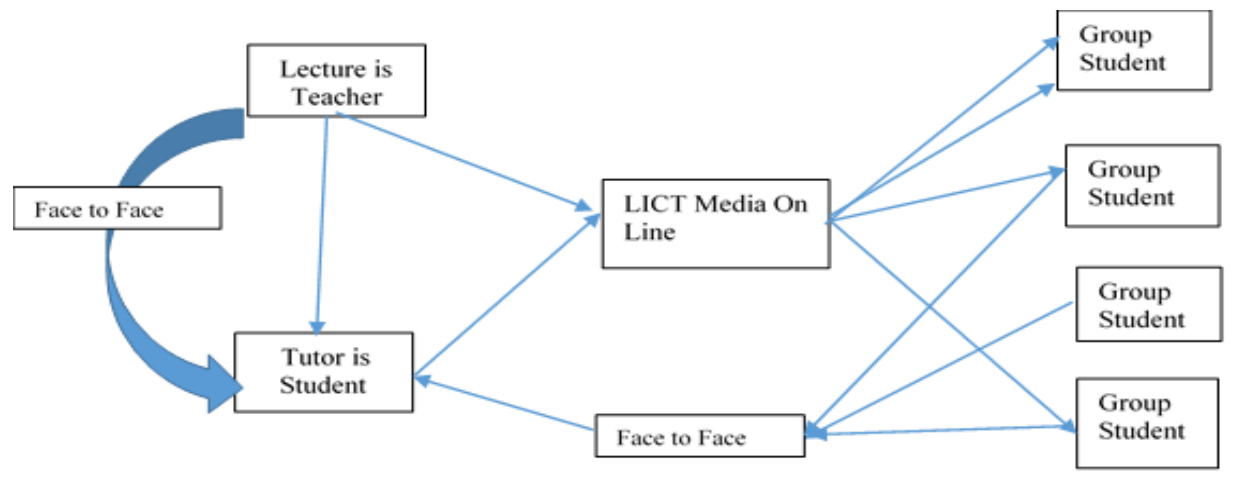

Fig. 1. Blended in Cooperative Learning Models

Fig. 1 is the development of behavior developed in the internet-based learning model that is character-based from Cooperative Learning activities. In the process of learning activities emphasizing the role of members in each group member has clear tasks and functions, meaning that group members play a role as a proponent, reconciler, mobilizer, decision maker and formulation of learning material that has been discussed with the teacher and tutor to be students and facilitators in on-line learning activities.

\section{Research Objectives}

Increased interest and willingness of students to learn a material is determined from the behavior of students in using information communication technology. The implication of cultural change and high levels of institutional resources are required to implement and to operate technology-mediated learning programs, and that few objective assessments of the performance of these programs are initially undertaken. (Alavi \& Gallupe, 2017). The changes that will and are happening are caused by the potential of information and communication technology capabilities that enable people to interact and meet their almost unlimited needs for information. The concept was a combination of Blended Learning with cooperative learning. it is called as Blended in Cooperative Learning (BCL) with the design of online learning models using SQLThe research goal that must be achieved in this study is to find a Blended 


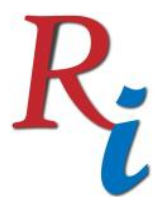

\section{Asia Proceedings of Social Sciences \\ (APSS) \\ www.readersinsight.net/APSS}

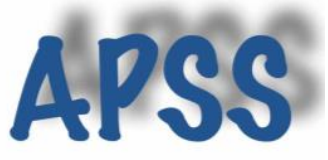

learning learning model design to increase the independence and creativity of students. Development of cooperative learning models based on blended learning is learning models to behavioral problems of students in utilizing computer/gagget-based communication and information technology in improving individual abilities through group learning. The results of this study will be expected to be applied to prospective teacher students in vocational schools so that they can improve their abilities to become professional teacher candidates in the fields of technology and engineering.

\section{Methodology}

The research method used to produce certain products, and test the effectiveness of these products. This research was about the fundamental phenomenon of education for the 4.0 era which was conducted through basic research, which was carried out through applied research. Some applied research was deliberately directed at developing a product, some other researches are developing products accidentally, because in their research they were contain or demand product development. To find out the efficacy of distance learning models compared to faceto-face learning, demanding the development of modules or teaching materials that will be used in distance learning conducted by students who had been approved by the teacher. Making modules or teaching materials was done to explore ICT literacy in the era of information technology environment. Evaluative method, used to evaluate the process of testing the development of a teaching material developed by students. Products are developed through a series of trials, and every evaluation activity is held, both results evaluation and process evaluation. Among the many approaches to technology-enhanced learning environments, research-based design is one of the most appropriate approaches for designing and evaluating a learning mix (Barab, 2004).

\section{Results}

This process, for students to study computers / technology during undergraduate education before meeting with students who will become during their services in the future. The level of success of students in terms of doing learning activities. it is interesting to learn more, because it turns out students are certainly motivated by the Self Directed Learning (SDL) project, but it is not clear whether the SDL project motivates or requires motivation to complete it based on 


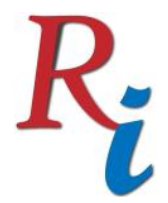

\section{Asia Proceedings of Social Sciences \\ (APSS) \\ www.readersinsight.net/APSS}

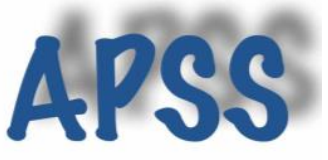

content analysis alone. (Boyer, Edmondson, Artist, \& Fleming, 2014). Based on qualitative data, the difference in learning outcomes in groups is better than individual learning outcomes. By allowing students to participate in determining online class activities based on their own way of behaving based on their own decisions that are carried out gradually and giving students the opportunity to express, improve and utilize their abilities as individuals who must work with students in a collaborative group environment. Reflective teaching depictions as creative problem solving activities and inquiry approaches that lead to constructivism in teaching and giving priority and successfully paying attention to the feelings of other students.

\section{Findings}

Teachers and students can think about what they want to achieve in class before practice and they try to follow up on the material needed to achieve the learning objectives. This is as stated by Henderson (1996) that the presence of reflective preparation activities makes the teacher relieved before coming to class. This is evident from the level of student participation in online classes both groups are more successful than online individually. Blended in Cooperative Learning (BCL) is learning together in Literacy ICT and education media for teacher to learner and learner to learner. The https://medialiterasiict.com. tool for learning models in technology and engineering for vocational education had been proven to be effective in shaping the character of students in responsible teamwork.

\section{Acknowledgement}

This research work is supported by the Project grant research Department of the Department of Electrical Engineering in Education Faculty of Technology and Vocational by Indonesian University of Education.

\section{References}

Alavi , M., \& Gallupe, R. (2017). Using Information Technology in Learning: Case Studies in Business and Management Education Programs. Academy of Management Learning \& Education, 139-153 Vol.2 No.2.

Arends, R. (2009). Learning to Teach. New York: Published by McGraw-Hill. 


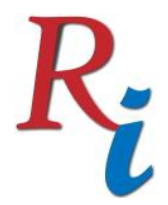

\section{Asia Proceedings of Social Sciences \\ (APSS) \\ www.readersinsight.net/APSS}

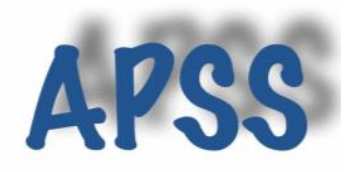

Boyer, S., Edmondson, D., Artis, A., \& Fleming, D. (2014). Self-Directed Learning: A Tool for Lifelong Learning. New york: Journal of Marketing Education SAGE Publishing.

Graham, C. (2004). BLENDED LEARNING SYSTEMS:DEFINITION, CURRENT TRENDS, AND FUTURE DIRECTIONS. In C. J. Bonk, Handbook of blended learning: Global Perspectives, local designs. (p. CHAPTER 1.1). San Francisco : CA: Pfeiffer Publishing.

Hadjerrouit, S. (2008). Towards a Blended Learning Model for Teaching and Learning Computer Programming: A Case Study. Informatics in Education, Volume $7,\{181-210$. Harding, A., Kaczynski, D., \& Wood, L. (2014). Evaluation of blended learning: analysis of qualitative data. Symposium Presentation, 56-62.

Ralph, R., Code, J., \& Petrina, S. (2019). Measuring theory of mind (ToM) with preschoolaged children: storybooks and observations with iPads. International Journal of Early Years Education, 1.

Barab, S. a. (2004). Design-based research: putting a stake in the ground. The Journal of the. The Journal of the Learning Sciences, , 13(1), 1-14.

Bates, A. (2005). Technology, e-learning and distance educationn (2nd ed.). New York: Routledge.

Bruner, J. (1996). Te narrative construal of reality. In J. Bruner, The culture of education (pp. (pp. 130-149).). Cambridge, : MA: Harvard University Press.

Khoe. Y. Tung. (2000). Teknologi Jaringan Intranet, . Yogyakarta: Andi.

Knowles, M. S. (1975). Self-directed learning. New York : Association Press.

Knowles, M. S. (1975). Self-directed learning: A guide for learners and teachers. Englewood Cliffs: NJ: Prentice Hall.

Marty, O. (2015, 25 Nov 2015 Rabu). Distance education ethics: How technique impacts morality and deontology. . HAL Id: halshs-01233793, pp. 1-16.

Meyer, M., \& Rakhkochkine, A. (2018, Vol. 17(1) ). Wolfgang Klafki's concept of'Didaktik' and its reception in Russia. European Educational Research Journal sagepub.co.uk/journals, 17-36.

Shih, R. (2010). Blended learning using video-based blogs: Public speaking for English as a second language students. Autralasia Journal of Educational Technology, 26 (6) 883897. 


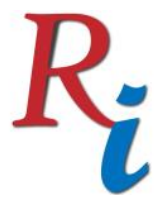

\section{Asia Proceedings of Social Sciences}

(APSS)

www.readersinsight.net/APSS

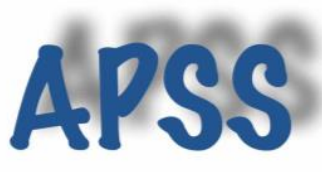

Torrance, E. P. (1988). The nature of creativity as manifest in its testing. In R.J. Sternberg (Ed.), The nature of creativity (pp. (pp. 43-75). ). New York: New York.

Wang, , F., \& M.J. , H. (2003). Importance of design-based research for technology-enhanced learning. In Proceedings of E-LEARN 2003, Phoenix, Arizona, November 7-11, 18131816.

Zeki Kaya, S. A. (2016). LEARNING AND TEACHING. Çözüm Eğitim Yayıncılık. Ankara, Turkey: https://www.researchgate.net/publication/304119354.

Author's Biography

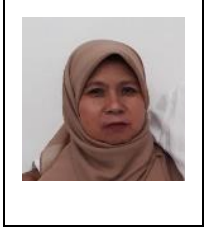

Dr. Tuti Suartini, born in Palembang, November 21, 1963. Obtained a Bachelor's degree from the Faculty of Technology and Vocational Education IKIP Bandung in 1985, then obtained a Masters in Education and Vocational in Yogyakarta State University in 2004. A Doctorate in the field of Technology and Vocational Education obtained at the University Indonesian Education in 2014. Started teaching at the Indonesian University of Education since 1986 as an Associate Assistant. Now as Associate Professor at the Indonesian University of Education. Since 1986 it has often participated in scientific meetings, both at national and international levels. The last one was in 2019 writing presented at an international scientific meeting and published in the sage open journal entitled Influence Application of Learning Models on Vocational Education Based on Quality Issues. SAGE Open, vol. 9, 2, First Published May 20, 2019.

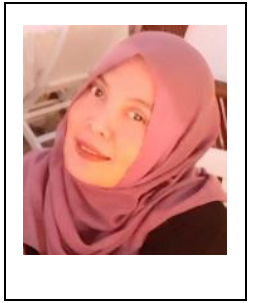

Dr.Siscka Elvyanti, MT was born in Bandung, Indonesia, in 1973. I received my Bachelor degree in education of electrical engineering from Universitas Pendidikan Indonesia (UPI) in 1999, the M. Tech degree in electrical engineering from Institut Technologi Bandung (ITB) in 2005, and Ph.D degree in vocational education from Universiti Tun Hussein Onn Malaysia (UTHM) in 2012.

In 2001, I joined the Department of Electrical Engineering Education, UPI as a lecturer. Lecturer with 18 years of experience specializing in education of electrical engineering and 


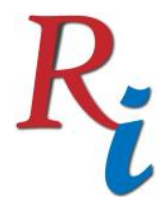

\section{Asia Proceedings of Social Sciences}

(APSS)

www.readersinsight.net/APSS

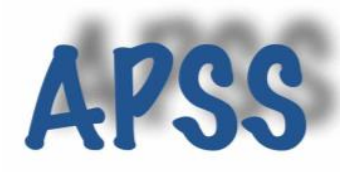

vocational education. As lecturer, my responsibilities including design hands-on lesson plan, develop teaching aids, create and administer oral, written, or performance exams of students, guidance academic counselors of students, and teaching. And as professional, from November 2018 until current, I have responsibility to restructure and redevelop one private polytechnic. My work responsible for planning, monitoring, and controlling the system implementation.

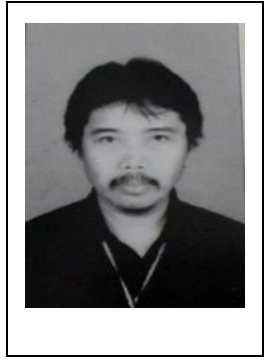

Dr. Enjang Akhmad Juanda M.Pd.,MT, A senior lecturer at Elektro Department, Technology and Vocational Education Faulty,Indonesia University of Education ( DPTE, FPTK, UPI), in Bandung, West Java, Indonesia.He is S1 graduated (begin in 1982) from DPTE, FPTK, UPI, S2 graduated from Guidance and Counseling ( Sekolah Pasca Sarjana) SPS, UPI, S2 graduated from Electro and Informatics School ( STEI) Bandung Insitute of Technology ( ITB) in Computer System Technique field, and S3 from STEI ITB. His career begin as a teacher in mathematics or algebra, electro technical skills, electrical machines, etc at General Senior High Schools) and vocational high schools ( STM, now SMK) about 1979. While he is as a teacher at SMA and STM, he officially accepted as General Public Employee of Indonesia in 1981. Some position he have ever helds is as DPTE, FPTK, UPI secretary, DPTE, FPTK, UPI head of Electro Technique Education Study Program, a senior Asessor of National Accreditation Board of Higher Education and some position in regional public affairs according to special needs from the public.

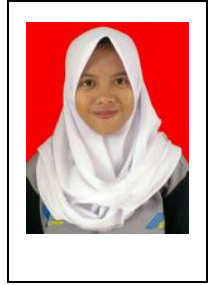

Tari Pramanik, Born in Bandung January 21, 1999. Now She is studying at Universitas Pendidikan Indonesia (UPI) with majoring Electrical Engineering of Education and become a teaching assistant in several subjects. Before She entered college at 4 Vocational High School Bandung and received and award as the best student. 